\title{
Pathological Choice: The Neuroscience of Gambling and Gambling Addiction
}

\author{
Luke Clark, ${ }^{1}$ Bruno Averbeck, ${ }^{2}$ Doris Payer, ${ }^{3}$ Guillaume Sescousse, ${ }^{4}$ Catharine A. Winstanley, ${ }^{5}$ and Gui Xue ${ }^{6}$ \\ ${ }^{1}$ Department of Psychology, University of Cambridge, Cambridge CB2 3EB, United Kingdom, ${ }^{2}$ Laboratory for Neuropsychology, National Institute of \\ Mental Health, Bethesda, Maryland 20892, ${ }^{3}$ Research Imaging Centre, Centre for Addiction and Mental Health, Toronto, Ontario M5T 1R8, Canada, \\ ${ }^{4}$ Donders Institute for Brain, Cognition and Behaviour, Radboud University Nijmegen, 6525 HP Nijmegen, The Netherlands, ${ }^{5}$ Department of Psychology, \\ University of British Columbia, Vancouver, British Columbia V6T 1Z4, Canada, and ${ }^{6}$ State Key Laboratory of Cognitive Neuroscience and Learning, and \\ IDG/McGovern Institute for Brain Research, Beijing Normal University, Beijing, China 100875
}

Gambling is pertinent to neuroscience research for at least two reasons. First, gambling is a naturalistic and pervasive example of risky decision making, and thus gambling games can provide a paradigm for the investigation of human choice behavior and "irrationality." Second, excessive gambling involvement (i.e., pathological gambling) is currently conceptualized as a behavioral addiction, and research on this condition may provide insights into addictive mechanisms in the absence of exogenous drug effects. This article is a summary of topics covered in a Society for Neuroscience minisymposium, focusing on recent advances in understanding the neural basis of gambling behavior, including translational findings in rodents and nonhuman primates, which have begun to delineate neural circuitry and neurochemistry involved.

\section{Introduction}

Gambling is a branch of the entertainment industry where patrons stake an object of value (typically money) on the uncertain prospect of a larger reward (the "jackpot"). Gambling dates back several millennia and remains ubiquitous across human societies, with lifetime gambling participation reported as $78 \%$ in the United States (Kessler et al., 2008). As such, gambling games serve as a useful model of risky choice, to the extent that laboratory tasks modeling the choice between two lotteries are regarded as "the fruitfly of behavioral economics" (Kahneman, 2011). In light of the widespread recognition that the expected value of gambling is negative ("the house always wins"), gambling games may shed further light on some of the errors and biases that characterize human decision making. Examining their underlying neural mechanisms is naturally relevant to the emergent discipline of neuroeconomics.

Gambling also has a more insidious side. Pathological gambling was first recognized as a psychiatric disorder in 1980 and was grouped initially in the Impulse Control Disorders. An inter-

Received July 30, 2013; revised Sept. 13, 2013; accepted Sept. 13, 2013. Author contributions: L.C., B.A., D.P., G.S., C.A.W., and G.X. wrote the paper.

L.C. was supported by the Medical Research Council (G1100554). B.A. was supported by the Intramural Research Program of the National Institute of Mental Health. C.A.W. was supported by the Canadian Institutes of Health Research (CIHR), the Canadian Natural Sciences and Engineering Research Council, Parkinson Society Canada, and the Canadian Foundation for Innovation and receives salary support through the Michael Smith Foundation for Health Research and the CIHR New Investigator Award program. G.X. was supported by the Natural Science Foundation of China (31130025). G.S. was supported by The Netherlands Organization for Scientific Research. D.P. was supported by Ontario Problem Gambling Research Centre 2642 and Canadian Institutes of Health Research (CIHR/ IRSC 258458). B.A., D.P., G.S., C.A.W., and G.X. are listed alphabetically.

The authors declare no competing financial interests.

Correspondence should be addressed to Dr. Luke Clark, Department of Psychology, University of Cambridge, Downing Street, Cambridge CB2 3EB, United Kingdom. E-mail: Ic260@cam.ac.uk.

DOI:10.1523/JNEUROSCI.3231-13.2013

Copyright $\odot 2013$ the authors $\quad 0270-6474 / 13 / 3317617-07 \$ 15.00 / 0$ national program of research over the past decade has revealed multiple similarities between pathological gambling and the substance use disorders, including neurobiological overlap (Petry, 2006, Leeman and Potenza, 2012). Whereas the comparability with obsessive compulsive disorders was also evaluated, the support for placement on a "compulsive spectrum" was mixed (Hollander and Wong, 1995). This process culminated in the recent reclassification of pathological gambling (now to be called "Gambling Disorder") into the addictions category of the DSM5 (Petry et al., 2013). This ratification of the so-called "behavioral addictions" is a pivotal step for not only the gambling field, but for addictions research in general.

The current article aims to provide a concise overview of recent developments in our understanding of decision making during gambling and the relevance of these processes to problem gambling (for comprehensive overviews, see van Holst et al., 2010; Hodgins et al., 2011; Leeman and Potenza, 2012). We begin by describing some emerging methods for probing gambling decisions, highlighting translational models, behavioral economic tasks, and cognitive distortions associated with gambling (Fig. 1). We then consider the underlying neural mechanisms, distinguishing neurochemical substrates and neuroanatomy.

\section{Models of gambling decisions: translational probes}

Given that the calculation of risk versus reward trade-offs is inherent in numerous aspects of real-world choice and foraging behavior, it should be unsurprising that laboratory animals are capable of performing decision-making tasks that resemble gambling. Recent work has aimed to model gambling decisions in rats using operant behavioral tasks derived from the established probes of choice behavior in human neuropsychology and cognitive psychology. One widely used human test is the Iowa Gambling Task (Bechara et al., 1994), which quantifies the deficits in 


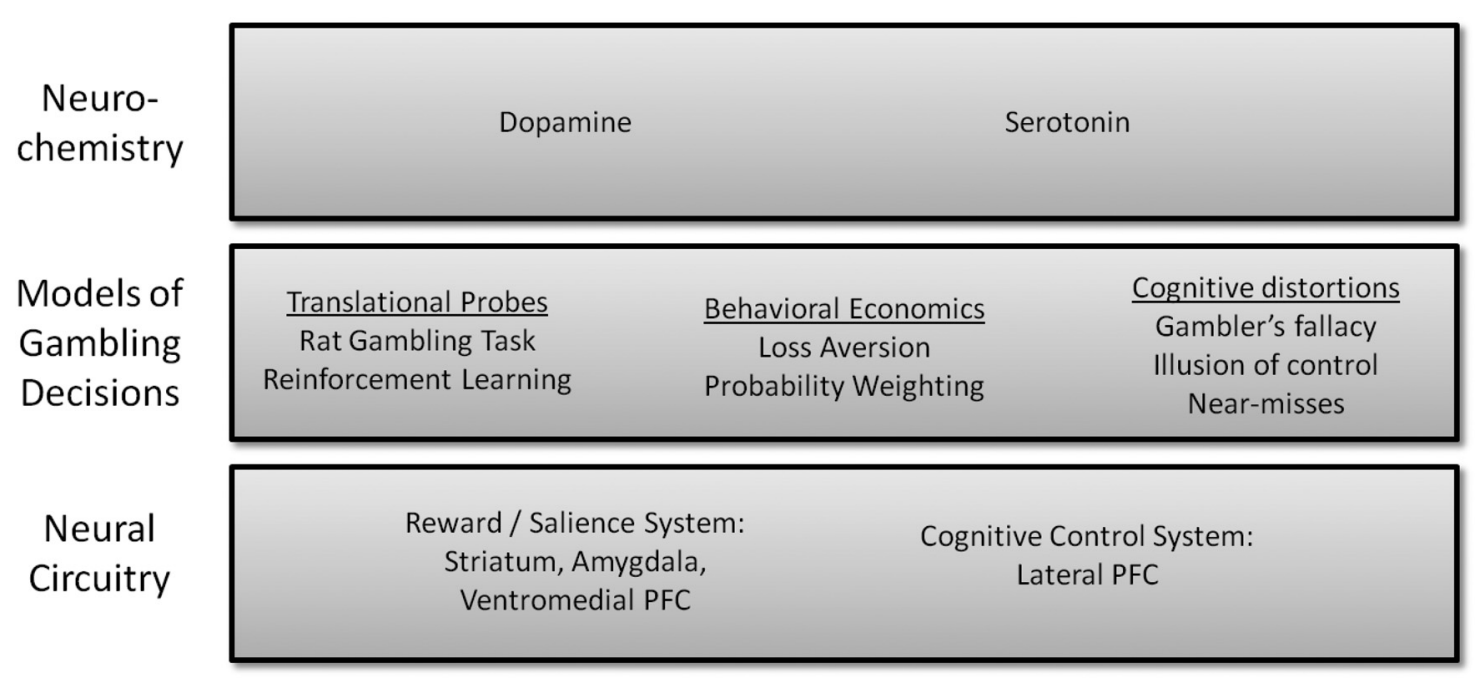

Figure 1. Schematic overview showing the emerging methods for modeling gambling decisions and the associated neural circuitry. The list is not intended as comprehensive but highlights the core themes covered in this review.

affective decision making seen after injury to the ventromedial prefrontal cortex. In humans, this task involves a series of choices between four decks of cards that offer gains and losses of varying amounts of money. A key challenge in translating the procedure into animals concerns the representation of "loss"; standard reinforcers, such as sugar pellets, are instantly consumed and thus cannot be deducted in the same way as money or points. In the rat Gambling Task (Zeeb et al., 2009), rats choose between four apertures that vary in the probability of delivering a smaller or larger number of sugar pellets, as well as the probability of receiving time-out penalties of varying durations. Like the human version, the two apertures that offer larger rewards are also associated with longer and more frequent time-outs, and most rats learn to avoid these tempting options to maximize their sugar pellet profits over the duration of the task. (The key decision here is probabilistic and the task should not be confused with temporal discounting).

Postacquisition lesions to BLA skewed rats' preference toward the high-risk high-reward options, matching the observation that amygdala damage leads to disadvantageous choice in the Iowa Gambling Task (Bechara et al., 1999; Zeeb and Winstanley, 2011). If BLA lesions were made before task acquisition, animals struggled to develop the optimal strategy and correctly discriminate between the options. Lesions to the orbitofrontal cortex (OFC) impaired acquisition of the rodent task in an identical manner but did not affect performance if the lesions were implemented after animals had learned the correct strategy. Such data support the suggestion that the classic disruption of everyday decision making associated with ventromedial prefrontal cortex lesions may stem from a difficulty in learning the optimal strategy, rather than an increase in preference for risky outcomes per se (Bechara et al., 2000; Fellows and Farah, 2005). Moreover, the similarity between the effects of BLA and OFC lesions on task acquisition suggested that these two areas work together to promote development of the optimal strategy, a hypothesis recently confirmed using a functional disconnection procedure (Zeeb and Winstanley, 2013). Hence, similar brain regions appear to be involved in guiding decision making under uncertainty in both rats and humans.

Prefrontal connectivity with the striatum is also implicated in choice behavior. Contemporary hypotheses of frontostriatal function emphasize a primary role in either action selection or reinforcement learning, both of which are likely important in substance addiction and behavioral addictions. To differentiate these elements, Seo et al. (2012) trained monkeys on a task in which they had to select rewarding actions using either reinforcement learning or perceptual inference. While the animals performed this task, neural activity was monitored simultaneously in anatomically connected regions of lateral prefrontal cortex (LPFC; caudal area 46) and the dorsal striatum (DS, primarily the anterior caudate nucleus). A larger fraction of LPFC neurons represented selected actions, independent of how they were selected. In the perceptual inference condition, the LPFC representation of the selected action preceded the DS representation of the selected action, whereas in the reinforcement learning condition, both structures represented the actions up to $500 \mathrm{~ms}$ before they were executed, with no clear temporal ordering. Additionally, DS more often represented the value of the selected action when it was selected using both perceptual inference and reinforcement learning. Thus, a hypothesis that the DS was important for action selection was not supported, but DS did often represent action values, when driven by either reinforcement learning or perceptual inference. LPFC, by contrast, appears to play a dominant role in representing and selecting actions, particularly when the selection is based on perceptual inference.

\section{Insights from behavioral economics}

Behavioral economic aims to decompose the processes of option valuation into simple components that can be quantified with discrete parameters (Schonberg et al., 2011). Prospect theory (PT) remains the most influential of these accounts because of its ability to describe a range of common behaviors and deviations from normative expected value theory (Kahneman and Tversky, 1979). A central feature of PT is "loss aversion," referring to the empirical observation that humans (and other species) are more sensitive to losses than to gains. For example, subjects typically reject mixed gambles that offer a 50-50 chance of winning or losing a given amount of money. Loss aversion may be underpinned by value computations in the ventral striatum and amygdala (Tom et al., 2007; De Martino et al., 2010) and has been shown to be modulated by thalamic norepinephrine (Takahashi et al., 2013). In addition to this asymmetry between gains and losses, PT describes a value function for gains that is concave, 
contrasting with a value function for losses that is convex. This disparity accounts for subjects' tendency to be risk averse in the gain domain and risk seeking in the loss domain, which may account for the "loss chasing" behavior that is characteristic of problem gamblers (Campbell-Meiklejohn et al., 2008, 2011). Although recent work has demonstrated impaired processing of loss information (Brevers et al., 2012) and aversive signals (Brunborg et al., 2012) in pathological gamblers, loss aversion is yet to be formally quantified in pathological gamblers.

$\mathrm{PT}$ also posits nonlinearity in probability calibration, whereby small probabilities are overestimated and medium to high probabilities are underestimated, in an inverse S-shaped "probability weighting function." These subjective distortions are reflected in brain activity profiles observed in the ventral striatum and dorsolateral prefrontal cortex (Tobler et al., 2008; Hsu et al., 2009) and also correlate with striatal dopamine $\mathrm{D}_{1}$ receptor density (Takahashi et al., 2010). Behaviorally, the overestimation of small probabilities may contribute to the attractiveness of gambles, such as a lottery (Trepel et al., 2005). Ligneul et al. (2013) tested this hypothesis in pathological gamblers, calculating "certainty equivalents" across varying levels of objective probability from 0 to 1 . As expected, the results revealed elevated risk taking in gamblers compared with nongambling controls; however, this behavior was not linked to a specific distortion of small probabilities but rather to a general overweighting across the entire probability range. Similar approaches using the discounting framework have demonstrated fine alterations of value representations in the ventral striatum in pathological gamblers (Miedl et al., 2012; Peters et al., 2012).

\section{Gambling-related cognitive distortions}

In addition to the computational characterization of gambling offered by behavioral economics, psychological models of gambling have additionally highlighted the central role of cognitive distortions during gambling. These distortions refer to how the gambler thinks about randomness, chance, and skill (Ladouceur and Walker, 1996; Clark, 2010) and foster an inappropriately high expectation of winning during the game. A number of specific biases have been described, and these cognitions can be effectively targeted as one element of psychotherapy for pathological gambling (Fortune and Goodie, 2012).

Arguably, the most classic distortion is the gambler's fallacy, which is a bias in the processing of random sequences. In this compelling example, the expectancy of a certain event (e.g., heads in a coin flip) becomes less likely after a long series of the same event (e.g., three successive tails). The phenomenon occurs across many situations, including casino gambling (Sundali and Croson, 2006), but also stock investment (Johnson et al., 2005). It is widely viewed as arising from the representativeness heuristic, the belief that a short segment of a random sequence should reflect the overall distribution (Rabin, 2002; Ayton and Fischer, 2004). Another archetypal distortion is the "illusion of control," referring to the interpretation of skill involvement in situations that are governed by chance alone (Langer, 1975; Stefan and David, 2013). Illusory control can be fostered by a various psychological features of games, such as the involvement of a choice (e.g., choosing a lottery ticket), instrumental action (e.g., throwing a roulette ball), or apparent competition (Langer, 1975). A recent study using a contingency judgment task from the associative learning literature found that pathological gamblers displayed a greater tendency to overestimate their control of positive outcomes than nongambling participants (Orgaz et al., 2013). Other recent work has considered the impact of "near miss" out- comes, unsuccessful outcomes that are proximal to a major win (Kassinove and Schare, 2001). Using a slot machine task that delivered occasional jackpot wins, near misses (where the reels landed adjacent to a win) were associated with higher selfreported motivations to gamble than full-miss outcomes, despite their objective equivalence as nonwins (Clark et al., 2009). To date, most of the research on these distortions has been in healthy samples; and although questionnaire measures, such as the Gambling Related Cognitions Scale (Raylu and Oei, 2004), indicate a clear increase in the overall propensity toward these erroneous beliefs in pathological gamblers (Michalczuk et al., 2011), there remain few empirical demonstrations that pathological gamblers are oversensitive to specific biases.

\section{Neurochemical substrates: dopamine dysregulation}

Dopamine has been a prime candidate for investigation of neurochemical abnormalities in pathological gamblers, given its established roles in both drug addiction and rewarded behavior. In patients with Parkinson's disease, sudden onset gambling can be observed, alongside other reward-driven behaviors, including compulsive shopping and hypersexuality, as a side effect of dopamine agonist medications (Ambermoon et al., 2011; Voon et al., 2011). The most direct approach for quantifying dopamine transmission in human brain is PET imaging of dopamine ligands, of which the most widely studied is $\left[{ }^{11} \mathrm{C}\right]$-raclopride, a $\mathrm{D}_{2 / 3}$ receptor antagonist that binds predominantly in the striatum. Building upon evidence for robust reductions in striatal dopamine $\mathrm{D}_{2 / 3}$ receptor availability in substance users dependent on a number of distinct drugs (Martinez et al., 2004; Volkow et al., 2007; Fehr et al., 2008), recent studies have used this ligand in pathological gamblers (Linnet et al., 2011; Clark et al., 2012; Joutsa et al., 2012; Boileau et al., 2013). Notably, none of these studies has detected a significant group difference in dopamine $\mathrm{D}_{2 / 3}$ binding, although some individual differences have been observed, for example, against trait impulsivity (Clark et al., 2012).

Ongoing work is using alternative PET tracers that offer advantages over $\left[{ }^{11} \mathrm{C}\right]$-raclopride. $\left[{ }^{11} \mathrm{C}\right]-(+)$-Propyl-hexahydronaphtho-oxazin (PHNO) is a $\mathrm{D}_{2 / 3}$ receptor agonist that binds preferentially to $\mathrm{D}_{3}$ over $\mathrm{D}_{2}$ receptors in vivo (Narendran et al., 2006). The $D_{3}$ receptor subtype is localized to limbic circuitry and implicated in drug self-administration and relapse behavior in preclinical models (Heidbreder et al., 2005). As a dopamine receptor agonist, $\left[{ }^{11} \mathrm{C}\right]-(+)-\mathrm{PHNO}$ is also more sensitive to displacement by endogenous dopamine than $\left[{ }^{11} \mathrm{C}\right]$-raclopride (an antagonist) (Willeit et al., 2008). A recent PET study using $\left[{ }^{11} \mathrm{C}\right]-$ $(+)$-PHNO in methamphetamine abusers indicated higher baseline binding in the $\mathrm{D}_{3}$-rich substantia nigra and pallidum, coupled with lower binding in the $\mathrm{D}_{2}$-rich dorsal striatum (Boileau et al., 2012). Employing a multimodal PET design in pathological gamblers using both $\left[{ }^{11} \mathrm{C}\right]-(+)$-PHNO and $\left[{ }^{11} \mathrm{C}\right]$-raclopride (Boileau et al., 2013), no group differences were detected, but a positive correlation was observed between gambling severity scores and $\left[{ }^{11} \mathrm{C}\right]-(+)$-PHNO binding in substantia nigra, a region where signal is fully attributable to $\mathrm{D}_{3}$ (Tziortzi et al., 2011). This association suggests that $\mathrm{D}_{3}$ expression is relevant to symptom severity in problem gambling, and as an addiction phenotype, it may be a useful marker for risk.

Preliminary work has also begun to examine dopamine release in pathological gamblers, with some provocative early findings. The change in $\left[{ }^{11} \mathrm{C}\right]-(+)$-PHNO binding was examined after a challenge dose of oral amphetamine $(0.4 \mathrm{mg} / \mathrm{kg})$ in pathological gamblers: greater dopamine release was detected in the dorsal (associative) 
striatum in the pathological gamblers (D. Payer, I. Boileau, D. Lobo, B. Chugani, A. Behzadi, A. Wilson, S. J. Kish, S. Houle, M. Zack, unpublished observations). This result effect is echoed in two further experiments examining task-related changes in $\left[{ }^{11} \mathrm{C}\right]$-raclopride binding in pathological gamblers, where higher levels of dopamine release were correlated with greater subjective excitement (Linnet et al., 2011) and gambling severity (Joutsa et al., 2012). Notably, the available data in drug addiction show blunted dopamine release in response to psychostimulant administration (Volkow et al., 1997; Martinez et al., 2007). The extent to which these discrepancies reflect etiological differences between substance and behavioral addictions, or the masking of incentive sensitization processes via drug-induced depletion of dopamine stores (Robinson and Berridge, 2003), is a key question in ongoing research.

Rodent models have also provided a means of examining the neurochemistry of gambling, implicating dopamine and serotonin influences. In light of the effects of dopamine agonist medications in Parkinson's disease, it is notable that administration of selective $\mathrm{D}_{2}$ agonists did not affect choice behavior on the rat Gambling Task (Zeeb et al., 2009). However, whereas the $D_{2}$ receptor antagonist eticlopride improved choice of the best option, amphetamine and the 5- $\mathrm{HT}_{1 \mathrm{~A}}$ agonist 8-OH-DPAT were found to impair performance (Zeeb et al., 2009). Selective dopamine antagonists did not block the effects of amphetamine on choice, even though such agents did attenuate amphetamine-induced increases in motor impulsivity (Zeeb et al., 2013). Furthermore, amphetamine's effects were not mimicked by dopamine, 5-HT, or noradrenaline reuptake inhibitors but were reproduced by different combinations of these drugs (Baarendse et al., 2013). Such results imply concurrent regulation of choice behavior on the rat Gambling Task by multiple monoaminergic systems, consistent with human data (Rogers, 2011).

A modified choice procedure in the rodent has been used to assess the sensitivity to stake size, implicating striatal $\mathrm{D}_{2 / 3}$ transmission specifically (Cocker et al., 2012). In this task, the rats choose between two options of equivalent value, one of which delivers a guaranteed reward, and the other offers either double that reward or nothing, with 50:50 odds. The reward size varies over the session from 1 to 3 pellets. Whereas some animals are largely indifferent to this "escalation of commitment," other rats become markedly risk avoidant as the stake increases, increasing their preference for the guaranteed option (CampbellMeiklejohn et al., 2012; Sescousse and den Ouden, 2013). Critically, such a behavioral shift confers no advantage in terms of reward earned and may be considered irrational in a similar vein to the framing effects observed in human choice under risk. PET imaging using ${ }^{11} \mathrm{C}$-raclopride revealed that $\mathrm{D}_{2 / 3}$ receptor binding in the dorsal striatum correlated significantly with the degree of wager-sensitivity rats exhibited. Moreover, in a key advantage over human PET imaging, it was possible to use autoradiography to confirm that the differences in raclopride binding were the result of lower levels of $\mathrm{D}_{2 / 3}$ receptor expression, as opposed to variation in endogenous dopamine levels.

\section{Functional neuroimaging of reward-related circuitry}

Functional neuroimaging studies have also contributed much to our understanding of appetitive processing in pathological gamblers and provide data that complement the investigations of dopamine transmission (Schott et al., 2008). Several fMRI studies in pathological gamblers have reported blunted neural responses to monetary gains and appetitive cues, primarily in ventral striatum and orbital/lateral PFC (Reuter et al., 2005; de Ruiter et al., 2009; Balodis et al., 2012). This observation can be interpreted in terms of the reward deficiency hypothesis (Comings and Blum, 2000), consistent with the PET evidence reviewed above indicating reduced dopamine receptor levels in addiction. However, other recent studies have described increased, rather than decreased, responses to monetary rewards in the same population (Hewig et al., 2010 using EEG; van Holst et al., 2012 using fMRI), prompting ongoing debate about the impact of naturalistic cues and stage of processing (anticipation vs outcome) in these effects (Leyton and Vezina, 2013; Limbrick-Oldfield et al., 2013).

One means of resolving these discrepancies is to consider the sensitivity to nonmonetary (i.e., nonaddiction related) rewards in gamblers. Using an incentive delay protocol involving both monetary and visual erotic rewards, pathological gamblers showed a markedly decreased response to the erotic cues, compared with monetary cues, in the ventral striatum (Sescousse et al., 2013). This differential response was correlated with the severity of gambling symptoms and accompanied by a similarly reduced behavioral motivation for erotic rewards. Comparable designs indicate blunted brain responses to non-drug-related cues in drug-addicted groups (Goldstein et al., 2007; Wrase et al., 2007; Bühler et al., 2010). These findings suggest that the key variable of interest may be the differential response to monetary (or drug) rewards versus other (primary) appetitive cues, rather than the response to money or drugs per se.

Experiments on gambling-related cognitive distortions also implicate reward-related circuitry, as well as the interactions with regions responsible for top-down cognitive control. Specifically, the gambler's fallacy appears to arise from an imbalance between cognitive and emotional decision making mechanisms in the brain (Shiv et al., 2005; Xue et al., 2011). Using a card guessing task to capture subjects' tendency to predict the break of a streak as it continued (a signal of the gambler's fallacy), enhanced neural responses in left LPFC were observed to outcomes that were followed by a gambler's fallacy switch (Xue et al., 2012b). A follow-up experiment applied anodal transcranial direct current stimulation, a procedure known to enhance cortical excitability and cerebral perfusion (Stagg et al., 2013), over the same region. Corroborating the fMRI data, stimulation to left LPFC increased the use of the gambler's fallacy (Xue et al., 2012b) and point to a causal role of this region in implementing this suboptimal decision strategy, guided by false world models.

Extending this interpretation in a larger sample of college students $(N=438)$, the use of the gambler's fallacy was positively correlated with general intelligence (Raven's matrices) and executive function (2-back working memory and Stroop tasks) but was negatively correlated with affective decision making (Iowa Gambling Task) (Xue et al., 2012a). Thus, the gambler's fallacy seems to be associated with (1) weak function in the affective decision making system and (2) strong function in the LPFC cognitive control system (Xue et al., 2011, 2012b).

In contrast to these cortical responses, the robust striatal activations seen in response to monetary wins are not evidently modulated by the psychological context that characterizes these gambling distortions. For example, the striatal responses to winning outcomes did not differ between the first win in a streak, compared with the fourth successive win (Akitsuki et al., 2003). In a study investigating the illusion of control, striatal activity did not differ between choice and no-choice conditions, even though perceived control did enhance subjective confidence (Kool et al., 2013). However, both distortions appear to be coded in higher cortical regions. Using a card guessing game to compare trials where either the subject or computer predicted the location of the winning card, agency affected not only the amount bet but also 
subjects' "world model" regarding the outcome dependency (Xue et al., 2013). Functional imaging results revealed that the decision-related activation in the lateral and medial PFC was significantly modulated by both agency and previous outcome and that these effects were further predicted by the trait-like disposition to attribute negative events externally. These results suggest that the prefrontal decision making system can be modulated by abstract beliefs and are thus vulnerable to factors, such as false agency and attribution.

Nevertheless, subcortical responses have been observed to near-miss outcomes during a simulated slot machine task. Specifically, these events recruited overlapping neural circuitry to the jackpot wins in the ventral striatum, amygdale, and anterior insula (Clark et al., 2009; Shao et al., 2013). Of these responses, the effect in the insula was seen to covary with trait levels of gambling distortions and individual differences in the motivational effect of the near misses (Clark et al., 2009). Administering a behavioral version of the slot machine game to patients with focal brain injury, a group with insula lesions was seen to be insensitive to near misses (i.e., did not show the typical motivational response) and also failed to manifest the gambler's fallacy (L. Clark, B. Studer, J. Bruss, D. Tranel, A. Bechara, unpublished observations). Thus, these results again highlight how gambling cognitions and persistent play are most likely to emerge from an imbalance between bottom-up emotional systems and prefrontal control systems, rather than a disruption in either component in isolation.

In conclusion, studies of cognitive processing during gambling have begun to uncover a wealth of phenomena that are relevant to problematic gambling, and useful as more general models of human decision making. The arsenal of tasks that probe gambling-related decision making can be implemented in other mental health problems associated with decision making disruption, including schizophrenia (Balzan et al., 2013), obsessive compulsive disorder (Reuven-Magril et al., 2008), and suicidal behavior (Dombrovski et al., 2011). The convergence with translational models of choice behavior in nonhuman species carries enormous potential for delineating the neural circuitry. Thus far, the translational work has progressed primarily in the area of value-based decision making, highlighting the roles of prefrontal cortex, striatum, and amygdala, innervating by ascending dopamine and serotonin inputs. Further progress may be achieved by modeling constructs from behavioral economics, and gambling-related cognitive distortions, in nonhuman species. For example, recent data from a rodent slot machine task indicate that rats are susceptible to near-miss outcomes and that erroneous attempts to collect reward on near-miss trials were dramatically increased by the $\mathrm{D}_{2}$-receptor agonist quinpirole (Winstanley et al., 2011). Interestingly, these effects appear to be mediated by the $\mathrm{D}_{4}$ receptor subtype specifically, leading to the exciting possibility that $\mathrm{D}_{4}$ receptor antagonists may be a useful treatment for compulsive slot machine play (P. Cocker, B. Le Foll, R. Rogers, C. A. Winstanley, unpublished observations).

Studies of patients with pathological gambling are also beginning to provide clues about the mechanisms involved in addiction. One interpretation of the null results from investigations of $\left[{ }^{11} \mathrm{C}\right]$-raclopride binding in pathological gamblers is that the robust reductions observed in drug addiction may represent a consequence of long-term drug exposure, rather than a preexisting vulnerability marker (Groman et al., 2012). Over the coming decade, we anticipate a similar program of research for other candidate behavioral addictions, such as excessive online video gaming (Kim et al., 2011; Kühn et al., 2011).

\section{References}

Akitsuki Y, Sugiura M, Watanabe J, Yamashita K, Sassa Y, Awata S, Matsuoka H, Maeda Y, Matsue Y, Fukuda H, Kawashima R (2003) Contextdependent cortical activation in response to financial reward and penalty: an event-related fMRI study. Neuroimage 19:1674-1685. CrossRef Medline

Ambermoon P, Carter A, Hall WD, Dissanayaka NN, O'Sullivan JD (2011) Impulse control disorders in patients with Parkinson's disease receiving dopamine replacement therapy: evidence and implications for the addictions field. Addiction 106:283-293. CrossRef Medline

Ayton P, Fischer I (2004) The hot hand fallacy and the gambler's fallacy: two faces of subjective randomness? Mem Cognit 32:1369-1378. CrossRef Medline

Baarendse PJ, Winstanley CA, Vanderschuren LJ (2013) Simultaneous blockade of dopamine and noradrenaline reuptake promotes disadvantageous decision making in a rat gambling task. Psychopharmacology 225: 719-731. CrossRef Medline

Balodis IM, Kober H, Worhunsky PD, Stevens MC, Pearlson GD, Potenza MN (2012) Diminished frontostriatal activity during processing of monetary rewards and losses in pathological gambling. Biol Psychiatry 71:749-757. CrossRef Medline

Balzan RP, Delfabbro PH, Galletly CA, Woodward TS (2013) Illusory correlations and control across the psychosis continuum: the contribution of hypersalient evidence-hypothesis matches. J Nerv Ment Dis 201:319-327. CrossRef Medline

Bechara A, Damasio AR, Damasio H, Anderson SW (1994) Insensitivity to future consequences following damage to human prefrontal cortex. Cognition 50:7-15. CrossRef Medline

Bechara A, Damasio H, Damasio AR, Lee GP (1999) Different contributions of the human amygdala and ventromedial prefrontal cortex to decisionmaking. J Neurosci 19:5473-5481. Medline

Bechara A, Tranel D, Damasio H (2000) Characterization of the decisionmaking deficit of patients with ventromedial prefrontal cortex lesions. Brain 123:2189-2202. CrossRef Medline

Boileau I, Payer D, Houle S, Behzadi A, Rusjan PM, Tong J, Wilkins D, Selby P, George TP, Zack M, Furukawa Y, McCluskey T, Wilson AA, Kish SJ (2012) Higher binding of the dopamine D3 receptor-preferring ligand $\left[{ }^{11} \mathrm{C}\right]-(+)$-propyl-hexahydro-naphtho-oxazin in methamphetamine polydrug users: a positron emission tomography study. J Neurosci 32: 1353-1359. CrossRef Medline

Boileau I, Payer D, Chugani B, Lobo D, Behzadi A, Rusjan PM, Houle S, Wilson AA, Warsh J, Kish SJ, Zack M (2013) The D2/3 dopamine receptor in pathological gambling: a positron emission tomography study with $\left[{ }^{11} \mathrm{C}\right]-(+)$-propyl-hexahydro-naphtho-oxazin and $\left[{ }^{11} \mathrm{C}\right]$ raclopride. Addiction 108:953-963. CrossRef Medline

Brevers D, Cleeremans A, Goudriaan AE, Bechara A, Kornreich C, Verbanck P, NoëlX (2012) Decision making under ambiguity but not under risk is related to problem gambling severity. Psychiatry Res 200:568-574. CrossRef Medline

Brunborg GS, Johnsen BH, Mentzoni RA, Myrseth H, Molde H, Lorvik IM, Bu ET, Pallesen S (2012) Diminished aversive classical conditioning in pathological gamblers. Addiction 107:1660-1666. CrossRef Medline

Bühler M, Vollstädt-Klein S, Kobiella A, Budde H, Reed LJ, Braus DF, Büchel C, Smolka MN (2010) Nicotine dependence is characterized by disordered reward processing in a network driving motivation. Biol Psychiatry 67:745-752. CrossRef Medline

Campbell-Meiklejohn DK, Woolrich MW, Passingham RE, Rogers RD (2008) Knowing when to stop: the brain mechanisms of chasing losses. Biol Psychiatry 63:293-300. CrossRef Medline

Campbell-Meiklejohn D, Wakeley J, Herbert V, Cook J, Scollo P, Ray MK, Selvaraj S, Passingham RE, Cowen P, Rogers RD (2011) Serotonin and dopamine play complementary roles in gambling to recover losses. Neuropsychopharmacology 36:402-410. CrossRef Medline

Campbell-Meiklejohn D, Simonsen A, Scheel-Krüger J, Wohlert V, Gjerløff T, Frith CD, Rogers RD, Roepstorff A, Møller A (2012) In for a penny, in for a pound: methylphenidate reduces the inhibitory effect of high stakes on persistent risky choice. J Neurosci 32:13032-13038. CrossRef Medline

Clark L (2010) Decision-making during gambling: an integration of cognitive and psychobiological approaches. Philos Trans R Soc Lond B Biol Sci 365:319-330. CrossRef Medline

Clark L, Lawrence AJ, Astley-Jones F, Gray N (2009) Gambling near-misses 
enhance motivation to gamble and recruit win-related brain circuitry. Neuron 61:481-490. CrossRef Medline

Clark L, Stokes PR, Wu K, Michalczuk R, Benecke A, Watson BJ, Egerton A, Piccini P, Nutt DJ, Bowden-Jones H, Lingford-Hughes AR (2012) Striatal dopamine $\mathrm{D}(2) / \mathrm{D}(3)$ receptor binding in pathological gambling is correlated with mood-related impulsivity. Neuroimage 63:40-46. CrossRef Medline

Cocker PJ, Dinelle K, Kornelson R, Sossi V, Winstanley CA (2012) Irrational choice under uncertainty correlates with lower striatal $\mathrm{D}(2 / 3)$ receptor binding in rats. J Neurosci 32:15450-15457. CrossRef Medline

Comings DE, Blum K (2000) Reward deficiency syndrome: genetic aspects of behavioral disorders. Prog Brain Res 126:325-341. CrossRef Medline

De Martino B, Camerer CF, Adolphs R (2010) Amygdala damage eliminates monetary loss aversion. Proc Natl Acad Sci U S A 107:3788-3792. CrossRef Medline

de Ruiter MB, Veltman DJ, Goudriaan AE, Oosterlaan J, Sjoerds Z, van den Brink W (2009) Response perseveration and ventral prefrontal sensitivity to reward and punishment in male problem gamblers and smokers. Neuropsychopharmacology 34:1027-1038. CrossRef Medline

Dombrovski AY, Szanto K, Siegle GJ, Wallace ML, Forman SD, Sahakian B, Reynolds CF 3rd, Clark L (2011) Lethal forethought: delayed reward discounting differentiates high- and low-lethality suicide attempts in old age. Biol Psychiatry 70:138-144. CrossRef Medline

Fehr C, Yakushev I, Hohmann N, Buchholz HG, Landvogt C, Deckers H, Eberhardt A, Kläger M, Smolka MN, Scheurich A, Dielentheis T, Schmidt LG, Rösch F, Bartenstein P, Gründer G, Schreckenberger M (2008) Association of low striatal dopamine $\mathrm{D} 2$ receptor availability with nicotine dependence similar to that seen with other drugs of abuse. Am J Psychiatry 165:507-514. CrossRef Medline

Fellows LK, Farah MJ (2005) Different underlying impairments in decisionmaking following ventromedial and dorsolateral frontal lobe damage in humans. Cereb Cortex 15:58-63. Medline

Fortune EE, Goodie AS (2012) Cognitive distortions as a component and treatment focus of pathological gambling: a review. Psychol Addict Behav 2012:298 - 310. CrossRef Medline

Goldstein RZ, Alia-Klein N, Tomasi D, Zhang L, Cottone LA, Maloney T, Telang F, Caparelli EC, Chang L, Ernst T, Samaras D, Squires NK, Volkow ND (2007) Is decreased prefrontal cortical sensitivity to monetary reward associated with impaired motivation and self-control in cocaine addiction? Am J Psychiatry 164:43-51. CrossRef Medline

Groman SM, Lee B, Seu E, James AS, Feiler K, Mandelkern MA, London ED, Jentsch JD (2012) Dysregulation of D(2)-mediated dopamine transmission in monkeys after chronic escalating methamphetamine exposure. J Neurosci 32:5843-5852. CrossRef Medline

Heidbreder CA, Gardner EL, Xi ZX, Thanos PK, Mugnaini M, Hagan JJ, Ashby CR Jr (2005) The role of central dopamine D3 receptors in drug addiction: a review of pharmacological evidence. Brain Res Brain Res Rev 49:77-105. CrossRef Medline

Hewig J, Kretschmer N, Trippe RH, Hecht H, Coles MG, Holroyd CB, Miltner WH (2010) Hypersensitivity to reward in problem gamblers. Biol Psychiatry 67:781-783. CrossRef Medline

Hodgins DC, Stea JN, Grant JE (2011) Gambling disorders. Lancet 378: 1874-1884. CrossRef Medline

Hollander E, Wong CM (1995) Obsessive-compulsive spectrum disorders. J Clin Psychiatry 56 [Suppl 4]:3-6, discussion 53-55.

Hsu M, Krajbich I, Zhao C, Camerer CF (2009) Neural response to reward anticipation under risk is nonlinear in probabilities. J Neurosci 29:22312237. CrossRef Medline

Johnson J, Tellis GJ, Macinnis DJ (2005) Losers, winners, and biased trades. J Consumer Res 32:329.

Joutsa J, Johansson J, Niemelä S, Ollikainen A, Hirvonen MM, Piepponen P, Arponen E, Alho H, Voon V, Rinne JO, Hietala J, Kaasinen V (2012) Mesolimbic dopamine release is linked to symptom severity in pathological gambling. Neuroimage 60:1992-1999. CrossRef Medline

Kahneman D (2011) Thinking, fast and slow. New York: Penguin.

Kahneman D, Tversky A (1979) Prospect theory: an analysis of decision under risk. Econometrica 47:264-291.

Kassinove JI, Schare ML (2001) Effects of the "near miss" and the "big win" on persistence at slot machine gambling. Psychol Addict Behav 15:155158. CrossRef Medline

Kessler RC, Hwang I, LaBrie R, Petukhova M, Sampson NA, Winters KC, Shaffer HJ (2008) DSM-IV pathological gambling in the National Co- morbidity Survey Replication. Psychol Med 38:1351-1360. CrossRef Medline

Kim SH, Baik SH, Park CS, Kim SJ, Choi SW, Kim SE (2011) Reduced striatal dopamine D2 receptors in people with Internet addiction. Neuroreport 22:407-411. CrossRef Medline

Kool W, Getz SJ, Botvinick MM (2013) Neural representation of reward probability: evidence from the illusion of control. J Cogn Neurosci 25: 852-861. CrossRef Medline

Kühn S, Romanowski A, Schilling C, Lorenz R, Mörsen C, Seiferth N, Banaschewski T, Barbot A, Barker GJ, Büchel C, Conrod PJ, Dalley JW, Flor H, Garavan H, Ittermann B, Mann K, Martinot JL, Paus T, Rietschel M, Smolka MN, et al. (2011) The neural basis of video gaming. Transl Psychiatry 1:e53. CrossRef Medline

Ladouceur R, Walker M (1996) A cognitive perspective on gambling. In: Trends in cognitive and behavioural therapies (Salkovskis PM, ed), pp 89-120. Chichester, United Kingdom: Wiley.

Langer EJ (1975) The illusion of control. J Pers Soc Psychol 32:311-328. CrossRef

Leeman RF, Potenza MN (2012) Similarities and differences between pathological gambling and substance use disorders: a focus on impulsivity and compulsivity. Psychopharmacology 219:469-490. CrossRef Medline

Leyton M, Vezina P (2013) Striatal ups and downs: their roles in vulnerability to addictions in humans. Neurosci Biobehav Rev. Advance online publication. Retrieved Jan. 16, 2013. doi: 10.1016/j.neubiorev.2013.01.018. CrossRef Medline

Ligneul R, Sescousse G, Barbalat G, Domenech P, Dreher JC (2013) Shifted risk preferences in pathological gambling. Psychol Med 43:1059-1068. CrossRef Medline

Limbrick-Oldfield EH, Van Holst RJ, Clark L (2013) Fronto-striatal dysregulation in drug addiction and pathological gambling: consistent inconsistencies? Neuroimage 2:385-393. CrossRef

Linnet J, Møller A, Peterson E, Gjedde A, Doudet D (2011) Dopamine release in ventral striatum during Iowa Gambling Task performance is associated with increased excitement levels in pathological gambling. Addiction 106:383-390. CrossRef Medline

Martinez D, Broft A, Foltin RW, Slifstein M, Hwang DR, Huang Y, Perez A, Frankle WG, Cooper T, Kleber HD, Fischman MW, Laruelle M (2004) Cocaine dependence and D2 receptor availability in the functional subdivisions of the striatum: relationship with cocaine-seeking behavior. Neuropsychopharmacology 29:1190-1202. CrossRef Medline

Martinez D, Narendran R, Foltin RW, Slifstein M, Hwang DR, Broft A, Huang Y, Cooper TB, Fischman MW, Kleber HD, Laruelle M (2007) Amphetamine-induced dopamine release: markedly blunted in cocaine dependence and predictive of the choice to self-administer cocaine. Am J Psychiatry 164:622-629. CrossRef Medline

Michalczuk R, Bowden-Jones H, Verdejo-Garcia A, Clark L (2011) Impulsivity and cognitive distortions in pathological gamblers attending the UK National Problem Gambling Clinic: a preliminary report. Psychol Med 41:2625-2635. CrossRef Medline

Miedl SF, Peters J, Büchel C (2012) Altered neural reward representations in pathological gamblers revealed by delay and probability discounting. Arch Gen Psychiatry 69:177-186. CrossRef Medline

Narendran R, Slifstein M, Guillin O, Hwang Y, Hwang DR, Scher E, Reeder S, Rabiner E, Laruelle M (2006) Dopamine (D2/3) receptor agonist positron emission tomography radiotracer $\left[{ }^{11} \mathrm{C}\right]-(+)-\mathrm{PHNO}$ is a $\mathrm{D} 3$ receptor preferring agonist in vivo. Synapse 60:485-495. CrossRef Medline

Orgaz C, Estévez A, Matute H (2013) Pathological gamblers are more vulnerable to the illusion of control in a standard associative learning task. Front Psychol 4:306. CrossRef Medline

Peters J, Miedl SF, Büchel C (2012) Formal comparison of dual-parameter temporal discounting models in controls and pathological gamblers. PLoS One 7:e47225. CrossRef Medline

Petry NM (2006) Should the scope of addictive behaviors be broadened to include pathological gambling? Addiction 101 [Suppl 1]:152-160.

Petry NM, Blanco C, Auriacombe M, Borges G, Bucholz K, Crowley TJ, Grant BF, Hasin DS, O'Brien C (2013) An overview of and rationale for changes proposed for pathological gambling in DSM-5. J Gambl Stud. Advance online publication. Retrieved March 23, 2013. doi: 10.1007/ s10899-013-9370-0. CrossRef Medline

Rabin M (2002) Inference by believers in the law of small numbers. Q J Econ 117:775-816. CrossRef

Raylu N, Oei TP (2004) The Gambling Related Cognitions Scale (GRCS): 
development, confirmatory factor validation and psychometric properties. Addiction 99:757-769. CrossRef Medline

Reuter J, Raedler T, Rose M, Hand I, Gläscher J, Büchel C (2005) Pathological gambling is linked to reduced activation of the mesolimbic reward system. Nat Neurosci 8:147-148. CrossRef Medline

Reuven-Magril O, Dar R, Liberman N (2008) Illusion of control and behavioral control attempts in obsessive-compulsive disorder. J Abnorm Psychol 117:334-341. CrossRef Medline

Robinson TE, Berridge KC (2003) Addiction. Annu Rev Psychol 54:25-53. CrossRef Medline

Rogers RD (2011) The roles of dopamine and serotonin in decision making: evidence from pharmacological experiments in humans. Neuropsychopharmacology 36:114-132. CrossRef Medline

Schonberg T, Fox CR, Poldrack RA (2011) Mind the gap: bridging economic and naturalistic risk-taking with cognitive neuroscience. Trends Cogn Sci 15:11-19. CrossRef Medline

Schott BH, Minuzzi L, Krebs RM, Elmenhorst D, Lang M, Winz OH, Seidenbecher CI, Coenen HH, Heinze HJ, Zilles K, Düzel E, Bauer A (2008) Mesolimbic functional magnetic resonance imaging activations during reward anticipation correlate with reward-related ventral striatal dopamine release. J Neurosci 28:14311-14319. CrossRef Medline

Seo M, Lee E, Averbeck BB (2012) Action selection and action value in frontal-striatal circuits. Neuron 74:947-960. CrossRef Medline

Sescousse G, den Ouden HE (2013) Gambling rats and gambling addiction: reconciling the role of dopamine in irrationality J Neurosci 338:32563258. CrossRef Medline

Sescousse G, Barbalat G, Domenech P, Dreher JC (2013) Imbalance in the sensitivity to different types of rewards in pathological gambling. Brain 136:2527-2538. CrossRef Medline

Shao R, Read J, Behrens TE, Rogers RD (2013) Shifts in reinforcement signalling while playing slot-machines as a function of prior experience and impulsivity. Transl Psychiatry 3:e235. CrossRef Medline

Shiv B, Loewenstein G, Bechara A, Damasio H, Damasio AR (2005) Investment behavior and the negative side of emotion. Psychol Sci 16:435-439. Medline

Stagg CJ, Lin RL, Mezue M, Segerdahl A, Kong Y, Xie J, Tracey I (2013) Widespread modulation of cerebral perfusion induced during and after transcranial direct current stimulation applied to the left dorsolateral prefrontal cortex. J Neurosci 33:11425-11431. CrossRef Medline

Stefan S, David D (2013) Recent developments in the experimental investigation of the illusion of control: a meta-analytic review. J Appl Soc Psychol 43:377-386. CrossRef

Sundali J, Croson R (2006) Biases in casino betting: the hot hand and the gambler's fallacy. Judgment Decision Making 1:1-12.

Takahashi H, Matsui H, Camerer C, Takano H, Kodaka F, Ideno T, Okubo S, Takemura K, Arakawa R, Eguchi Y, Murai T, Okubo Y, Kato M, Ito H, Suhara T (2010) Dopamine D(1) receptors and nonlinear probability weighting in risky choice. J Neurosci 30:16567-16572. CrossRef Medline

Takahashi H, Fujie S, Camerer C, Arakawa R, Takano H, Kodaka F, Matsui H, Ideno T, Okubo S, Takemura K, Yamada M, Eguchi Y, Murai T, Okubo Y, Kato M, Ito H, Suhara T (2013) Norepinephrine in the brain is associated with aversion to financial loss. Mol Psychiatry 18:3-4. CrossRef Medline

Tobler PN, Christopoulos GI, O’Doherty JP, Dolan RJ, Schultz W (2008) Neuronal distortions of reward probability without choice. J Neurosci 28:11703-11711. CrossRef Medline

Tom SM, Fox CR, Trepel C, Poldrack RA (2007) The neural basis of loss aversion in decision-making under risk. Science 315:515-518. CrossRef Medline

Trepel C, Fox CR, Poldrack RA (2005) Prospect theory on the brain? Toward a cognitive neuroscience of decision under risk. Brain Res Cogn Brain Res 23:34-50. CrossRef Medline

Tziortzi AC, Searle GE, Tzimopoulou S, Salinas C, Beaver JD, Jenkinson M,
Laruelle M, Rabiner EA, Gunn RN (2011) Imaging dopamine receptors in humans with $\left[{ }^{11} \mathrm{C}\right]-(+)$-PHNO: dissection of D3 signal and anatomy. Neuroimage 54:264-277. CrossRef Medline

van Holst RJ, van den Brink W, Veltman DJ, Goudriaan AE (2010) Why gamblers fail to win: a review of cognitive and neuroimaging findings in pathological gambling. Neurosci Biobehav Rev 34:87-107. CrossRef Medline

van Holst RJ, Veltman DJ, Büchel C, van den Brink W, Goudriaan AE (2012) Distorted expectancy coding in problem gambling: is the addictive in the anticipation? Biol Psychiatry 71:741-748. CrossRef Medline

Volkow ND, Wang GJ, Fowler JS, Logan J, Gatley SJ, Hitzemann R, Chen AD, Dewey SL, Pappas N (1997) Decreased striatal dopaminergic responsiveness in detoxified cocaine-dependent subjects. Nature 386:830-833. CrossRef Medline

Volkow ND, Fowler JS, Wang GJ, Swanson JM, Telang F (2007) Dopamine in drug abuse and addiction: results of imaging studies and treatment implications. Arch Neurol 64:1575-1579. CrossRef Medline

Voon V, Sohr M, Lang AE, Potenza MN, Siderowf AD, Whetteckey J, Weintraub D, Wunderlich GR, Stacy M (2011) Impulse control disorders in Parkinson disease: a multicenter case-control study. Ann Neurol 69:986996. CrossRef Medline

Willeit M, Ginovart N, Graff A, Rusjan P, Vitcu I, Houle S, Seeman P, Wilson AA, Kapur S (2008) First human evidence of d-amphetamine induced displacement of a D2/3 agonist radioligand: $\mathrm{a}\left[{ }^{11} \mathrm{C}\right]-(+)-\mathrm{PHNO}$ positron emission tomography study. Neuropsychopharmacology 33:279-289. CrossRef Medline

Winstanley CA, Cocker PJ, Rogers RD (2011) Dopamine modulates reward expectancy during performance of a slot machine task in rats: evidence for a "near-miss" effect. Neuropsychopharmacology 36:913-925. CrossRef Medline

Wrase J, Schlagenhauf F, Kienast T, Wüstenberg T, Bermpohl F, Kahnt T, Beck A, Ströhle A, Juckel G, Knutson B, Heinz A (2007) Dysfunction of reward processing correlates with alcohol craving in detoxified alcoholics. Neuroimage 35:787-794. CrossRef Medline

Xue G, Lu Z, Levin IP, Bechara A (2011) An fMRI study of risk-taking following wins and losses: implications for the gambler's fallacy. Hum Brain Mapp 32:271-281. CrossRef Medline

Xue G, He Q, Lei X, Chen C, Liu Y, Chen C, Lu ZL, Dong Q, Bechara A (2012a) The gambler's fallacy is associated with weak affective decision making but strong cognitive ability. PLoS One 7:e47019. CrossRef Medline

Xue G, Juan CH, Chang CF, Lu ZL, Dong Q (2012b) Lateral prefrontal cortex contributes to maladaptive decisions. Proc Natl Acad Sci U S A 109:4401-4406. CrossRef Medline

Xue G, He Q, Lu ZL, Levin IP, Dong Q, Bechara A (2013) Agency modulates the lateral and medial prefrontal cortex responses in belief-based decision making. PLoS One 8:e65274. CrossRef Medline

Zeeb FD, Winstanley CA (2011) Lesions of the basolateral amygdala and orbitofrontal cortex differentially affect acquisition and performance of a rodent gambling task. J Neurosci 31:2197-2204. CrossRef Medline

Zeeb FD, Winstanley CA (2013) Functional disconnection of the orbitofrontal cortex and basolateral amygdala impairs acquisition of a rat gambling task and disrupts animals' ability to alter decision-making behavior after reinforcer devaluation. J Neurosci 33:6434-6443. CrossRef Medline

Zeeb FD, Robbins TW, Winstanley CA (2009) Serotonergic and dopaminergic modulation of gambling behavior as assessed using a novel rat gambling task. Neuropsychopharmacology 34:2329-2343. CrossRef Medline

Zeeb FD, Wong AC, Winstanley CA (2013) Differential effects of environmental enrichment, social-housing, and isolation-rearing on a rat gambling task: dissociations between impulsive action and risky decision-making. Psychopharmacology 225:381-395. CrossRef Medline 